\title{
Korelasi Kadar Seng Serum dan Bangkitan Kejang Demam
}

\author{
Iva-Yuana, * Tjipta Bahtera, * Noor Wijayahadi** \\ *Bagian Ilmu Kesehatan Anak / RSUP Dr Kariadi / Fakultas Kedokteran Universitas Diponegoro \\ Semarang \\ **Bagian Farmakologi Klinik Fakultas Kedokteran Universitas Diponegoro Semarang
}

Latar belakang. Kejang demam merupakan kelainan saraf tersering pada anak. Sekitar 2\%-5\% anak di bawah umur 5 tahun pernah mengalami kejang demam. Prognosis kejang demam baik, namun mengkhawatirkan orang tua. Penelitian tentang hubungan kadar seng serum dengan bangkitan kejang demam belum banyak dilakukan.

Tujuan. Membuktikan korelasi kadar seng serum dan bangkitan kejang demam.

Metode. Penelitian kasus kontrol dengan subyek penelitian anak berumur 3 bulan- 5 tahun di RS Dr.Kariadi pada April 2009-Maret 2010, kelompok kasus dengan bangkitan kejang demam dan kelompok kontrol dengan demam tanpa kejang. Kadar seng serum diperiksa di laboratorium GAKI FK UNDIP dengan metode atomic absorption spectrophotometry. Data dianalisis dengan uji Chi-square, korelasi Spearman, dan analisis determinan.

Hasil. Subyek penelitian 72 pasien, 36 kelompok kasus dan 36 kelompok kontrol. Rerata kadar seng kelompok kasus $111,73 \mu \mathrm{g} / \mathrm{mL}$ dan kelompok kontrol 114,56 $\mu \mathrm{g} / \mathrm{mL}(\mathrm{p}=0,33)$. Tidak terdapat korelasi antara kadar seng serum dengan bangkitan kejang demam ( $r=0.114 ; p>0,05)$. Analisis determinan menunjukkan urutan besarnya kontribusi faktor genetik $(0,548)$, infeksi berulang $(0,493)$, riwayat penyulit kehamilan-persalinan $(0,364)$, suhu $(0,309)$, gangguan perkembangan otak $(0.141)$, kadar seng serum $(-0,102)$, umur $(-0,041)$ dengan confusion matrix $81,9 \%$ untuk prediksi.

Kesimpulan. Rerata kadar seng serum pada bangkitan kejang demam lebih rendah dibanding tanpa kejang demam, namun tidak bermakna. Tidak terdapat korelasi antara kadar seng serum dengan bangkitan kejang demam. Kadar seng serum bersama faktor genetik, infeksi berulang, penyulit dalam kehamilan maupun persalinan, suhu badan, gangguan perkembangan otak, dan umur dapat digunakan sebagai prediktor bangkitan kejang demam meskipun memiliki peranan kecil. Sari Pediatri 2010;12(3):150-6.

Kata kunci: kejang demam, kadar seng serum

\footnotetext{
Alamat korespondensi:

Dr. Tjipta Bahtera, Sp.A(K). Bagian IKA FK UNDIP/RSUP Dr.Kariadi.

Jl. Dr. Soetomo No. 16-18, Semarang. Telp. 024-8311471/8414296.

Dr. Iva Yuana. E-mail : ivadeka@gmail.com
}

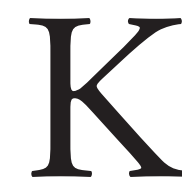

ejang demam adalah bangkitan kejang terkait dengan demam dan umur serta tidak didapatkan infeksi ataupun kelainan intrakranial. Demam terjadi apabila suhu 
tubuh rektal di atas $38^{\circ} \mathrm{C}$ atau suhu tubuh aksila $37,8^{\circ} \mathrm{C}$. Pada umumnya kejang demam terjadi pada umur 3 bulan sampai 5 tahun, dan terbanyak pada umur 14-18 bulan. ${ }^{1,2}$ Kejang demam merupakan kelainan tersering pada anak 2\%-5\% anak berumur di bawah 5 tahun pernah mengalami bangkitan kejang demam. Di Amerika Serikat insiden kejang demam berkisar antara $2 \%-5 \%$ pada anak umur kurang dari lima tahun. Di Asia angka kejadian kejang demam dilaporkan lebih tinggi dan sekitar 80\%-90\% dari seluruh kejang demam adalah kejang demam sederhana. Di Jepang angka kejadian kejang demam 9\%-10\%. ${ }^{1,3}$

Prognosis kejang demam baik, namun 25\%-50\% kejang demam akan mengalami bangkitan kejang demam berulang dan $4 \%$ pasien kejang demam dapat mengalami gangguan tingkah laku dan penurunan tingkat intelegensi. Insiden epilepsi akibat kejang demam berkisar antara 2\%-5\% dan meningkat hingga 9\%-13\% bila terdapat faktor risiko berupa riwayat keluarga dengan epilepsi, perkembangan abnormal sebelum kejang demam pertama, atau mengalami kejang demam kompleks. ${ }^{3}$ Selain itu, bangkitan kejang demam berulang dapat menimbulkan kekhawatiran orangtua pasien. Kepustakaan menyebutkan bahwa 47\%-77\% orangtua pasien kejang demam sangat mengkhawatirkan anaknya dan beranggapan bahwa penyakit anaknya berat dan berakhir dengan kematian. ${ }^{4}$

Kejang demam dapat terjadi karena adanya pengaruh beberapa hal, yaitu umur, faktor risiko saat kehamilan maupun persalinan yang menyebabkan trauma otak, suhu badan, faktor genetik, infeksi berulang dan ketidakseimbangan neurotransmitter inhibitor dan eksitator. ${ }^{5}$ Seng (Zn) merupakan antagonis $\mathrm{N}$ metil-D-aspartat (NMDA) sehingga kadar seng rendah diduga dapat mengaktivasi reseptor NMDA dan berperan dalam pengaturan eksitabilitas jalur sistem saraf pusat. Penelitian oleh Burhanoglu (1996) mendapatkan adanya penurunan kadar seng serum dan cairan serebrospinal pada pasien kejang demam. Sebaliknya, konsentrasi tembaga, magnesium, dan protein tidak mengalami penurunan. ${ }^{6}$ Penelitian Ganesh dan Janakiraman di India tahun 2005-2006 mendapatkan adanya hubungan antara kadar seng serum dengan kejang demam dengan OR 1.5.

Data dari International Conference of Zinc and Human Health tahun 2000 menyimpulkan bahwa diperkirakan $48 \%$ populasi dunia mempunyai risiko terjadi defisiensi seng, penelitian di Surakarta tahun 1988 pada 156 responden anak dan dewasa didapatkan $87,2 \%$ mengalami defisiensi seng. ${ }^{8}$ Penelitian belah lintang di Teheran (1997) pada 881 pelajar dengan usia rata-rata 13,2 tahun didapatkan 31,1\% mengalami defisiensi seng. ${ }^{9}$ Di Mexico (2001) insiden defisiensi seng $40 \%$ di daerah perkampungan sedangkan $18 \%$ di daerah perkotaan. ${ }^{10}$ Penelitian oleh Huwae tahun 2006 pada 111 anak usia 6 tahun-8 tahun di Grobogan Jawa Tengah didapatkan $40 \%$ anak mengalami defisiensi seng. ${ }^{11}$

Penelitian tentang hubungan kadar seng serum dengan bangkitan kejang demam belum banyak dilakukan dan belum diketahui besarnya peranan kadar seng serum terhadap terjadinya bangkitan kejang demam. Penelitian dilakukan untuk menganalisis korelasi antara kadar seng serum dengan bangkitan kejang demam serta menganalisis peranan kadar seng serum bersama dengan faktor risiko lain yaitu faktor genetik, infeksi berulang, riwayat penyulit dalam kehamilan maupun persalinan, suhu badan, riwayat gangguan perkembangan otak, dan umur terhadap bangkitan kejang demam.

\section{Metode}

Desain penelitian kasus kontrol yang dilakukan di Bagian Ilmu Kesehatan Anak, Sub Bagian Neurologi dan Sub Bagian Infeksi dan Penyakit Tropik. RSUP dr. Kariadi Semarang mulai bulan April 2009 sampai Maret 2010. Subyek penelitian dipilih dengan metode consecutive sampling yaitu berdasarkan kedatangan pasien dengan kriteria inklusi usia 3 bulan-5 tahun yang mengalami kejang demam berlangsung kurang dari 15 menit sebagai kasus dan pasien umur 3 bulan- 5 tahun yang mengalami demam selama $<7$ hari tanpa disertai kejang sebagai kontrol. Pasien dengan gangguan metabolik, infeksi intrakranial, memiliki riwayat epilepsi sebelumnya, mengalami kejang demam dan mendapat profilaksis kontinyu, serta menolak untuk diikutsertakan dalam penelitian tidak dimasukkan dalam penelitian. Selanjutnya dilakukan anamnesis, pemeriksaan fisik, dan pemeriksaan laboratorium meliputi darah rutin, gula darah sewaktu, elektrolit, dan kadar seng serum. Pengambilan darah vena dilakukan oleh tenaga medis. Pemeriksaan kadar seng serum di laboratorium GAKI FK UNDIP Semarang dengan metode atomic absorption spectrophotometry 
(AAS). Evaluasi klinis dilakukan selama tiga hari untuk memastikan tidak didapatkan adanya infeksi intrakranial maupun perburukan secara klinis.

Analisis statistik dilakukan dengan uji chi-square, uji Fisher's, dan analisis korelasi Spearman dilanjutkan analisis determinan dengan program SPSS for Windows versi 15 . Penelitian dilakukan setelah mendapat persetujuan dari Komisi Etik Penelitian Kesehatan (KEPK) Fakultas Kedokteran Universitas Diponegoro / RSUP dr. Kariadi Semarang.

\section{Hasil}

Subyek penelitian 47 pasien, 36 pasien memenuhi kriteria inklusi. Sebelas subyek tidak diikutsertakan dalam penelitian karena beberapa sebab yaitu umur lebih dari 5 tahun, didapatkan infeksi intrakranial pada pemantauan selanjutnya, atau orangtua/wali menolak mengikuti penelitian. Total subyek penelitian adalah 72 pasien yang memenuhi kriteria inklusi, terdiri dari 36 pasien dengan bangkitan kejang demam sebagai kasus dan 36 pasien dengan demam tanpa bangkitan kejang sebagai kontrol.

Tabel 2 menunjukkan bahwa faktor penyulit kehamilan dan persalinan, infeksi berulang, dan faktor genetik merupakan faktor risiko terjadinya bangkitan kejang demam. Hasil analisis korelasi Spearman menunjukkan bahwa tidak ada korelasi antara kadar seng serum dengan bangkitan kejang demam $(\mathrm{r}=0,114$, $\mathrm{p}=0,339$ ).

Analisis diskriminan mencakup variabel kejang

Tabel 1. Karakteristik subyek

\begin{tabular}{lccc}
\hline \multirow{2}{*}{ Variabel } & \multicolumn{2}{c}{ Kelompok } & \multirow{2}{*}{$\mathrm{p}$} \\
\cline { 2 - 3 } & \multicolumn{1}{c}{$\mathrm{KD}=36)$} & $\begin{array}{c}\text { Non KD } \\
(\mathrm{n}=36)\end{array}$ & $0,72^{\S}$ \\
\hline Umur rerata \pm SB (bulan) & $20,25( \pm 16,38)$ & $21,33( \pm 15,59)$ & \\
Jenis kelamin & $19(52,8 \%)$ & $20(55,6 \%)$ & $0,81^{*}$ \\
Laki-laki & $17(47,2 \%)$ & $16(44,4 \%)$ & $0,33^{\S}$ \\
Perempuan & $111,73( \pm 16,88)$ & $114,56( \pm 16,38)$ & \\
Kadar seng serum (ug/dL) & & & \\
\hline
\end{tabular}

*Uji chi-square $\quad$ ¿Uji Mann-Whitney

Tabel 2. Tabulasi silang antara beberapa variabel perancu dengan bangkitan kejang demam

\begin{tabular}{|c|c|c|c|c|}
\hline \multirow[t]{2}{*}{ Variabel } & \multicolumn{2}{|c|}{ Kelompok kejang demam } & \multirow{2}{*}{$\mathrm{OR}(95 \% \mathrm{CI})$} & \multirow[t]{2}{*}{$\mathrm{p}$} \\
\hline & kasus & kontrol & & \\
\hline \multicolumn{5}{|c|}{ Suhu badan $\left({ }^{\circ} \mathrm{C}\right)$} \\
\hline$\geq 38,9$ & 12 & 14 & $0,786(0,3-2,06)$ & $0,624^{*}$ \\
\hline$<38,9$ & 24 & 22 & & \\
\hline \multicolumn{5}{|c|}{ Penyulit kehamilan dan persalinan } \\
\hline Ada & 17 & 7 & $3,707(1,293-10,627)$ & $0,01^{*}$ \\
\hline Tidak ada & 19 & 29 & & \\
\hline \multicolumn{5}{|c|}{ Gangguan perkembangan otak } \\
\hline Ada & 1 & 0 & - & $1,00^{¥}$ \\
\hline Tidak ada & 35 & 36 & & \\
\hline \multicolumn{5}{|c|}{ Infeksi berulang (kali) } \\
\hline$\geq 4$ & 15 & 3 & $7,857(2,027-30,459)$ & $0,001^{*}$ \\
\hline$<4$ & 21 & 33 & & \\
\hline \multicolumn{5}{|l|}{ Faktor genetik } \\
\hline Ya & 13 & 1 & $19,783(2,42-161,692)$ & $0,00^{*}$ \\
\hline Tidak & 23 & 35 & & \\
\hline
\end{tabular}

${ }^{*} \mathrm{Uji}$ chi-square $¥$ Uji Fisher’s 
Tabel 3. Hasil klasifikasi

\begin{tabular}{lccc}
\hline \multirow{2}{*}{$\begin{array}{l}\text { Bangkitan kejang } \\
\text { demam }\end{array}$} & \multicolumn{2}{c}{ Prediksi kelompok } & \multirow{2}{*}{ Jumlah } \\
\cline { 2 - 3 } & Tidak & Ya & \\
\hline Tidak, $\mathrm{n}(\%)$ & $32(88,9)$ & $4(11,1)$ & 36 \\
Ya, $\mathrm{n}(\%)$ & $9(25)$ & $27(75)$ & 36 \\
\hline
\end{tabular}

Confusion matrix $81,9 \%$

demam maupun variabel tanpa kejang demam. Variabel diskriminan terdiri dari faktor genetik (ada atau tidak ada), riwayat penyulit dalam kehamilan maupun persalinan (ada atau tidak ada), infeksi berulang ( $\geq 4$ kali atau $<4$ kali dalam 1 tahun), riwayat gangguan perkembangan otak (ada atau tidak ada), suhu badan (dalam derajat Celcius), umur responden (dalam bulan), dan kadar seng serum (dalam ug/dL).

Didapatkan nilai kanonik 0,646 dengan $\mathrm{p}>0,05$ dan uji Wilks' Lambda=0,583 yang ditransformasikan dalam perhitungan chi-square 35.938 dengan $\mathrm{p}=0,000$ $(\mathrm{p}<0,05)$. Hasil analisis menunjukkan bahwa kejang demam mempunyai hubungan yang cukup kuat dengan faktor infeksi berulang, faktor genetik, riwayat penyulit dalam kehamilan maupun persalinan, kadar seng serum, riwayat gangguan perkembangan otak, suhu badan, dan umur. Terdapat perbedaan bermakna rata-rata skor diskriminan antara kelompok pasien kejang demam dengan tanpa kejang demam. Dengan demikian variabel-variabel tersebut dapat digunakan sebagai penduga timbulnya bangkitan kejang demam.

Confusion matrix $81,9 \%$ menunjukkan bahwa fungsi diskriminan yang terbentuk sangat kuat untuk dipakai memprediksi terjadinya bangkitan kejang demam. Rata-rata skor diskriminan untuk kelompok kejang demam 0,835 dan kelompok tanpa kejang demam $-0,835$, dengan cut off point $(0,829 \times 36-0$ ,829x36) : 72=0. Tanda (+) pada koefisien diskriminan berarti variabel bertambah besar, pasien cenderung tidak akan mengalami bangkitan kejang demam. Tanda (-) pada koefisien diskriminan mempunyai arti skor diskriminan bertambah kecil, pasien cenderung terjadi bangkitan kejang demam. Apabila skor diskriminan pasien demam mempunyai nilai di bawah nol, pasien akan mengalami bangkitan kejang demam dan sebaliknya. Fungsi standardized menunjukkan urutan besarnya kontribusi berbagai variabel untuk menentukan timbulnya bangkitan kejang demam berturut-turut adalah faktor genetik $(0,548)$, infeksi berulang $(0,493)$, riwayat penyulit dalam kehamilan maupun persalinan
$(0,364)$, suhu badan $(0,309)$, riwayat gangguan perkembangan otak $(0,141)$, kadar seng serum $(0,102)$ dan umur $(0,041)$.

\section{Pembahasan}

Beberapa karakteristik variabel pada penelitian ini seperti jenis kelamin, pendidikan ayah, pendidikan ibu, pekerjaan ayah, dan pekerjaan ibu menunjukkan tidak ada perbedaan yang bermakna antara kelompok kasus dengan kelompok kontrol.

Suhu bukan merupakan faktor risiko terjadinya bangkitan kejang demam. Penelitian Bahtera ${ }^{12}$ menunjukkan suhu badan saat timbul bangkitan kejang demam pertama pada pasien dengan mutasi gen lebih rendah dibandingkan pasien tanpa mutasi gen $\left(38^{\circ} \mathrm{C}\right.$ dibanding $\left.39^{\circ} \mathrm{C}\right)$. Pasien dengan mutasi gen memiliki ambang kejang rendah akibat adanya channelopathy. Channelopathy dapat mengakibatkan temperature sensitive sehingga dengan suhu tidak tinggi sudah terjadi bangkitan kejang demam. Penelitian Chan $\mathrm{dkk}^{13}$ menunjukkan bahwa suhu bukan merupakan faktor risiko terjadinya kejang demam berulang. Tidak ada perbedaan bermakna antara suhu badan pada kejang demam pertama maupun kejang demam berulang. Kesulitan yang dihadapi pada penelitian ini adalah tidak bisa mengetahui suhu badan secara tepat saat terjadi kejang demam. Suhu badan diukur setelah terjadi kejang dan tidak dilakukan pengukuran suhu badan sebelum kejang sehingga tidak diketahui peningkatannya. Hal ini menyebabkan suhu badan tidak akurat sebagai faktor risiko bangkitan kejang demam.

Adanya gangguan perkembangan otak tidak terbukti sebagai faktor risiko bangkitan kejang demam pada penelitian ini. Terdapat satu kasus dengan kecurigaan mengalami gangguan perkembangan berdasarkan hasil anamnesis dan pemeriksaan fisik pada saat pasien dirawat. Kurangnya sampel dengan gangguan perkembangan otak dapat mempengaruhi hasil ini.

Variabel penyulit kehamilan dan persalinan, infeksi berulang, dan faktor genetik terbukti merupakan faktor risiko bangkitan kejang demam. Beberapa penelitian yang dilakukan tahun 1985 sampai 1999 mendapatkan bahwa berat lahir rendah, prematuritas, partus macet, dan partus sungsang, merupakan faktor risiko bangkitan kejang demam. Faktor-faktor tersebut berkaitan dengan gangguan perkembangan otak yang mengakibatkan ambang kejang menurun. ${ }^{14}$ 
Penelitian Vestergaard ${ }^{15}$ menunjukkan paparan asap rokok $\geq 10$ batang perhari selama kehamilan memiliki risiko mengalami bangkitan kejang demam 1,25 kali lebih besar daripada tidak mendapatkan paparan asap rokok selama kehamilan. Paparan asap rokok selama kehamilan menurunkan oksigenasi dan mengganggu aliran darah janin sehingga menyebabkan gangguan perkembangan otak.Ling ${ }^{16}$ mendapatkan bahwa usia $<15$ bulan, berat lahir $<2 \mathrm{~kg}$, dan suhu awal $<38^{\circ} \mathrm{C}$ merupakan faktor risiko bangkitan kejang demam khususnya tipe kejang demam kompleks. Bayi dengan berat lahir rendah cenderung mengalami prematuritas atau retardasi pertumbuhan intrauterin sehingga lebih rentan terhadap risiko hipoksia. Penelitian Huang $\mathrm{dkk}^{17}$ mendapatkan faktor risiko bangkitan kejang demam adalah riwayat keluarga mengalami kejang demam (OR $3,1)$ dan infeksi berulang (OR 1,71). Pasien dengan dua atau lebih faktor risiko memiliki kemungkinan 28\% mengalami bangkitan kejang demam setidaknya satu kali. Faktor-faktor yang meningkatkan risiko berulang adalah keluarga memiliki riwayat kejang demam, usia saat kejang demam pertama kurang dari 12 bulan, serta derajat dan lamanya demam. ${ }^{1,13} \mathrm{Ada}$ anggota keluarga pasien (first degree relative) dengan riwayat pernah menderita kejang demam dan adanya channelopathy mempunyai risiko hampir 3 kali untuk terjadi bangkitan ulang kejang demam. Pada pasien kejang demam berulang lebih banyak didapatkan adanya mutasi gen pintu voltase kanal ion natrium dibanding pasien tanpa kejang demam berulang (77,8\% berbanding $22,2 \%) .{ }^{18}$

Hasil penelitian menunjukkan bahwa tidak ada korelasi antara kadar seng serum dengan bangkitan kejang demam. Namun demikian, kadar seng serum bersama variabel lainnya dapat dipakai sebagai faktor diskriminan terjadinya bangkitan kejang demam. Ganesh dan Janakiraman melakukan penelitian pada 38 anak dengan bangkitan kejang demam sebagai kasus dan 38 anak dengan demam kurang dari tiga hari tanpa bangkitan kejang yang datang di poliklinik rawat jalan sebagai kontrol. Hasil penelitian menunjukkan bahwa kadar seng serum pada anak dengan bangkitan kejang demam lebih rendah daripada anak dengan demam tanpa bangkitan kejang (32,17 ug/dL:87,6 ug/ dL). Anak dengan kadar seng serum rendah memiliki risiko 1,5 kali untuk mengalami bangkitan kejang demam. ${ }^{7}$

Penelitian oleh Ruiz $\mathrm{dkk}^{19}$ menunjukkan bahwa gangguan sensitivitas $\mathrm{Zn}^{2+}$ merupakan aspek penting yang mempengaruhi plastisitas transmisi GABAergik. Selain itu didapatkan bahwa status epileptikus berhubungan dengan turunnya sensitivitas $\mathrm{Zn}^{2+}$ reseptor GABA. Perubahan tersebut dapat terjadi karena gangguan ekspresi beberapa sub unit yang berpengaruh terhadap sensitivitas reseptor $\mathrm{Zn}^{2+}$.

Takeda $\mathrm{dkk}^{20}$ melakukan penelitian pada tikus berusia 12 minggu dan 8 minggu yang mengalami defisiensi seng dan tidak mengalami defisiensi seng sebagai kontrol. Konsentrasi seng diukur pada area korteks serebri, hipokampus, dan serebellum. Hasil penelitian menunjukkan bahwa konsentrasi seng di ketiga area tersebut pada tikus usia 12 minggu dengan defisiensi seng tidak berbeda secara signifikan dibandingkan dengan kontrol. Sedangkan pada tikus usia 8 minggu dengan defisiensi seng didapatkan penurunan konsentrasi seng di vesikel pre sinap dan dapat mempengaruhi pelepasan glutamat dari neuron terminal di hipokampus. Hal ini menunjukkan bahwa pada masa pertumbuhan cepat seperti masa kehamilan dan masa bayi, otak lebih rentan terhadap defisiensi seng. Seng dalam vesikel lebih responsif terhadap terjadinya defisiensi seng pada usia lebih muda.

Pendapat lain menyebutkan bahwa pada masa pasca natal awal, defisiensi seng mengurangi kadar mRNA dan protein untuk sub unit reseptor NMDA yaitu NR1, NR2A, dan NR2B. Pada masa developmental window, ekspresi sub unit reseptor NMDA sangat sensitif terhadap perubahan kadar seng. Kadar seng bebas dalam hipokampus tidak mengalami penurunan meskipun dilakukan restriksi asupan seng selama 4 minggu, namun demikian penurunan ekspresi sub unit NR1 dapat menetap meskipun defisiensi seng telah dikoreksi selama 65 hari. Kadar NR1 otak menetap di bawah 40\% dibanding kontrol setelah dilakukan koreksi. Penelitian kami mendukung teori bahwa defisiensi seng yang terjadi pada masa pertumbuhan cepat akan lebih bermakna menimbulkan gangguan fungsi otak. Hubungan antara kadar seng dalam diit dengan kadar seng bebas dan implikasinya terhadap pengaturan reseptor NMDA masih belum jelas. ${ }^{21} \mathrm{Hal}$ yang sama disebutkan oleh Sandstead dkk ${ }^{22}$ bahwa konsentrasi seng pada bayi baru lahir lebih rendah dibanding dewasa. Bayi kurang bulan memiliki afinitas seng lebih rendah daripada bayi cukup bulan. Defisiensi seng akan meningkatkan uptake seng dan berpengaruh terhadap otak terutama pada respon sinap di hipokampus. Pengaturan reseptor NMDA dapat dipengaruhi oleh kadar seng maupun afinitas 
seng terhadap reseptor glutamat.

Szewczyk $\mathrm{dkk}^{23}$ melakukan penelitian pada otak tikus dan mendapatkan bahwa seng dalam vesikel sinap paling berperan dalam proses neurotransmisi. Seng yang dilepaskan mempengaruhi eksitabilitas otak melalui modulasi kanal ion dan reseptor asam amino termasuk reseptor AMPA, NMDA, dan GABA. Pendapat tersebut didukung oleh Lee $\mathrm{dkk}^{24}$ yang menyatakan bahwa seng dalam vesikel merupakan seng bebas, tidak terikat protein, dan dilepaskan dari vesikel sinap apabila terjadi eksitasi neuron. Proses tersebut kemudian mempengaruhi beberapa aktivitas kanal ion. Kandungan seng dalam vesikel sinap tersebut dipengaruhi oleh adanya zinc transporter 3 (ZnT3) dalam vesikel sinap. Gen $\mathrm{ZnT}$ 3 dalam vesikel sinap ini tidak mempengaruhi kandungan seng non vesikuler. Seng di vesikel terdapat dalam jumlah relatif kecil dibandingkan total seng dalam otak namun merupakan faktor utama dari seluruh seng otak yang reaktif secara histokimia. $^{25}$

Huwae $^{11}$ melakukan penelitian terhadap 111 anak berumur 6 tahun -8 tahun di daerah yang memungkinkan terjadinya defisiensi seng. Kadar seng ditentukan dengan pemeriksaan seng rambut dan didapatkan adanya korelasi antara kadar seng rambut dengan memori jangka pendek, peningkatan kadar seng rambut akan disertai peningkatan skor memori jangka pendek. Kadar seng rambut dapat lebih tepat menggambarkan kecukupan seng pada masa lampau.

Pada penelitian kami kadar seng rambut tidak diukur untuk menunjukkan defisiensi seng kronis, tidak mengambil sampel khusus pada populasi dengan defisiensi seng, dan tidak dapat melakukan pemeriksaan suhu badan sebelum dan saat terjadi bangkitan kejang demam sehingga tidak dapat mengetahui peningkatan suhu secara tepat. Disimpulkan bahwa rerata kadar seng serum pada pasien kejang demam lebih rendah dibandingkan kadar seng serum pada pasien demam tanpa bangkitan kejang demam, tetapi secara statistik tidak bermakna. Tidak ada korelasi antara kadar seng serum dengan bangkitan kejang demam. Kadar seng serum bersama dengan variabel lainnya yaitu faktor genetik, infeksi berulang, penyulit dalam kehamilan maupun persalinan, suhu badan, gangguan perkembangan otak, dan umur dapat dipakai sebagai prediktor terhadap bangkitan kejang demam dengan kekuatan 81,9\% meskipun kadar seng serum memiliki peranan kecil. Disarankan melakukan penelitian lebih lanjut yang membandingkan kadar seng serum dari cairan serebrospinal dengan kadar seng rambut yang dapat menggambarkan defisiensi seng kronis dan pada populasi dengan defisiensi seng. Pada pasien dengan bangkitan kejang demam, belum perlu dilakukan pemeriksaan kadar seng serum.

\section{Daftar pustaka}

1. Widodo DP. Kejang demam : apa yang perlu diwaspadai? Dalam: Penanganan demam pada anak secara profesional. Pendidikan Kedokteran Berkelanjutan Ilmu Kesehatan Anak XLVII. Jakarta; 2005.h.58-66.

2. Johnston MV. Seizures in childhood. Dalam: Behrman RE, Kliegman RM, Jenson HB, penyunting. Nelson Textbook of Pediatrics. Edisi ke-18. Philadelphia: WB Saunders Co;2007.h.2457-71.

3. Stafstrom CE. The incidence and prevalence of febrile seizures. Dalam: Baram TZ, Shinnar S, penyunting, Febrile Seizures. San Diego : Academic press;2002.h.125.

4. Gordon KE, Dooley JM, Camfield PR, Camfield CS, MacSween J. Treatment of febrile seizures: the influence of treatment efficacy and side-effect profile on value to parents. Pediatrics 2001;108:1080-8.

5. Fisher RS, Wu J. Basic electrophysiology of febrile seizures. Dalam: Baram TZ, Shinnar S, penyunting. Febrile Seizures. San Diego : Academic press;2002.h.23147.

6. Burhanoglu M, Tutunouglu S, Coker C, Tekgul H, Ozgur T. Hypozincemia in febrile convulsion. Eur J Pediatr 1996;155:498-501.

7. Ganesh R, Janakiraman L. Serum zinc level in children with simple febrile seizure. Clin Pediatr (Phila) 2008;47:164-6.

8. Satoto. Zinc deficiency among Indonesian children. Dalam: Joint Symposium between Department of Nutrition \& Department of Paediatrics Faculty of Medicine, Sebelas Maret University and The Center of Human Nutrition, University of Shiffield, UK. Surakarta;2001.

9. Mahmoodi MR, Kimiagar SM. Prevalence of zinc deficiency in junior high school student of Teheran City. Bio Trace Elem Res 2001;81:93-103.

10. Rosado JL. Zinc and cooper : proposed fortification levels and recommended zinc compounds. J Nutr 2003;133:2985-9.

11. Huwae FJ. Hubungan antara kadar seng dengan memori jangka pendek pada anak sekolah dasar. Tesis. 2006. 
12. Bahtera T. Faktor risiko kejang demam berulang sebagai prediktor bangkitan kejang demam berulang. Kajian mutasi gen pintu voltase kanal ion natrium. (Disertasi). Semarang: Fakultas Kedokteran Universitas Diponegoro, 2007.

13. Chan KK, Cherk SWW, Chan CH, Ng DKK, Ho JCS. A retrospective review of first febrile convulsion and its risk factors for recurrence in Hong Kong children. HK J Paediatr 2007;12:181-7.

14. Camfield P, Camfield C, Gordon K. Antecedents and risk factors for febrile seizures. Dalam: Baram TZ, Shinnar $S$, penyunting. Febrile Seizures. San Diego: Academic press;2002.h.1-25.

15. Vestergaard M, Wisborg K, Henriksen TB, Secher NJ, Ostergaard JR, Olsen J. Prenatal exposure to cigarettes, alcohol, and coffee and the risk for febrile seizures. Pediatrics 2005;116:1089-94.

16. Ling SG. Clinical characteristics and risk factors for a complex first febrile convulsion. Singapore Med J 2001;42:264-7.

17. Huang CC, Wang ST, Chang YC, Huang MC, Chi YC, Tsai JJ. Risk factors for a first febrile convulsion in children : a population study in southern Taiwan. Epilepsia 1999;40:719-25.

18. Daoud A. Febrile convulsion : review and update. Journal of Pediatric Neurology 2004;2:14.

19. Ruiz A, Walker MC, Fabian-Fine R, Kullman D. Endogenous zinc inhibits $\mathrm{GABA}_{\mathrm{A}}$ receptors in a hippocampal pathway. J Neurophysiol 2004;91: 1091-6.

20. Takeda A, Tamano H, Tochigi M, Oku N. Zinc homeostasis in the hippocampus of zinc-deficient young adult rats. Neurochem Int 2005;221-5.

21. Levenson CW. Regulation of the NMDA receptor: implications for neuropsychological development. Nutri Rev 2006;64:428-32.

22. Sandstead HH, Frederickson CJ, Penland JG. History of zinc as related to brain function. J. Nutr. 2000;130:496502.

23. Szewczyk B, Sowa M, Czupryn A, Wieronska JM, Branski P, Sadlik K, et al. Increase in synaptic hippocampal zinc consentration following chronic but not acute zinc treatment in rats. Brain Res 2006;1090:69-75.

24. Lee JY, Cole TB, Palmiter RD, Koh JY. Accumulation of zinc in degenerating hippocampal neurons of $\mathrm{ZnT} 3-$ Null mice after seizures : evidence against synaptic vesicle origin. J Neurosci 2000;20:1-5.

25. Frederickson CJ, Suh SW, Silva D, Thompson RB. Importance of zinc in the central nervous system : the zinc-containing neuron. J. Nutr. 2000;130:1471-83. 